\title{
39. TERTIARY OXYGEN AND CARBON ISOTOPE STRATIGRAPHY, SITE 357 (MID LATITUDE SOUTH ATLANTIC)
}

\author{
Anne Boersma, Lamont-Doherty Geological Observatory of Columbia University, Palisades, New York \\ and \\ Nicholas Shackleton, Sub-Department of Quaternary Research, \\ University of Cambridge, England, and Lamont-Doherty Geological Observatory
}

\begin{abstract}
Detailed ${ }^{18} \mathrm{O}$ and ${ }^{13} \mathrm{C}$ records were constructed for the Tertiary at Site 357 (Leg 39, DSDP) on the Rio Grande Rise, South Atlantic. Samples were measured at intervals of closer than one per million years, except across hiatuses from the late Paleocene to early Eocene, late Eocene to early Oligocene, middle Miocene, and parts of the late Miocene.

A survey of planktonic foraminiferal depth habitats showed that during the Paleogene the keeled globorotalids and chiloguembelinids lived at warmer temperatures in the water column than other planktonics. Below these lived the acute-edged acarininids, globigerinathekids, hantkeninids, round-edged acarininids, globigerinids, and finally Catapsydrax. In the Oligocene the warmest species were the chiloguembelinids and the unkeeled globorotalids. These warmest forms were used where possible to construct a surface temperature curve. For the Miocene, Globigerinoides was used.

In the early Paleogene the surface temperature was about $19^{\circ}$ $20^{\circ} \mathrm{C}$, a temperature no higher than today at these latitudes. A marked temperature decline began in the latest middle Eocene, peaked in the late Eocene (Zone P16), and resulted in temperatures ranging from $12^{\circ}-6^{\circ} \mathrm{C}$ in the Oligocene, and nothing higher in the Miocene.

Several species of Paleogene benthic foraminifera ${ }^{1}$ were calibrated to the genus, Uvigerina, which has been shown to be in isotopic equilibrium in the Recent and late Tertiary. Stratigraphically longranging and geographically wide-ranging forms were calibrated, including Globocassidulina subglobosa, Pullenia bulloides. Oridorsalis umbonatus, and Cibicides perlucidus.

In the Paleocene to Eocene the bottom temperature on this segment of the Rio Grande Rise was about $12^{\circ} \mathrm{C}$; today this temperature water extends only to a depth of around 500 meters. The warm pool of Atlantic deep water was much more extensive in the Paleogene. The major drop in bottom water temperature began during the late middle Eocene (Zone P13) and reached $6^{\circ} \mathrm{C}$ by around 40 m.y., the late Eocene (Zone P16). The time of these low temperatures corresponds with hiatuses here and elsewhere across the Eocene/Oligocene boundary in the South Atlantic. It corresponds also with the temperature decrease noted at Site 277 in the South Pacific (called Oligocene there). The temperature dropped to $4^{\circ}$ in the middle Oligocene (Zone P21) and to a low of $3^{\circ}$ in the early Miocene (Zone N4). Such lows may be evidence for an intensification in the rate of production of Antarctic-derived bottom waters.
\end{abstract}

\footnotetext{
'The senior author has expressed strong preference for using "foraminifera" rather than the common form "foraminifer." Although the DSDP editors feel that the common form of the word is preferable in English, and have decided for consistency to use it in the Initial Reports, they accede here to the senior author's wishes.
} 
Faunal changes during the temperature decline in the Eocene, the temperature minimum in the middle Oligocene, and a temperature maximum in the early Miocene were recorded. Changing diversities, abundances, and species of planktonic foraminifera characterize changes in surface temperatures. Changing diversities, abundances, and morphotypic expressions of benthic foraminiferal species occur during changes in bottom temperatures.

\section{INTRODUCTION}

Stable isotope analyses were made on benthic and planktonic foraminifera from Site 357, DSDP Leg 39. The location and Tertiary stratigraphy of this site are shown in Figure 1.

The primary purpose of stable isotope analyses from Site 357 was to generate the first Tertiary paleotemperature curve for the mid-latitude Atlantic Ocean in order to look, if only cursorily, at some of the following:

1) the isotope record of the introduction of Antarctic Bottom Water in the late Oligocene as postulated during Leg 39;

2) the time of the late Eocene temperature drop in this area;

3) temperature maxima and minima at this site compared with published Pacific curves;

4) faunal fluctuations and the temperature record at selected intervals in the early and mid Tertiary on a ridge whose approximate depth has been estimated.

\section{ANALYTICAL PROCEDURE}

Analytical methods for oxygen isotope analysis were as described earlier (Shackleton and Opdyke, 1973). Samples were cleaned by ultrasonic vibration to remove adhering fine-grained material, and purified further by roasting in vacuo as $450^{\circ} \mathrm{C}$ for 30 minutes. Carbon dioxide for mass spectometric analysis was released by the action of $100 \%$ orthophosphoric acid at $50^{\circ} \mathrm{C}$ and transferred immediately to the mass spectrometer after the removal of water. Calibration to the PDB standard (Epstein et al., 1953) is probably accurate to better than 0.1 per mil, being effected by analyzing standard carbonates in the same way as the foraminiferal sample (Shackleton, 1974). Analytical precision, judged by repeated sampling of standard carbonates, is about \pm 0.07 per mil; overall precision is generally found to be about \pm 0.11 per mil, additional uncertainty deriving from variability among the individual foraminifera analyzed (Shackleton and Opdyke, 1973). In this study a small number of oùr analyses deviated by a greater amount; we interpret this as being due to reworking, down-slope movement, or down-hole contamination. Where possible we have analyzed two or more species separately; for accurate estimates of temperatures at the sea floor we regard concordance among different species as being very important.

\section{OCEAN ISOTOPIC COMPOSITION}

It is well known that prior to the accumulation of the Antarctic ice sheet the oceans were isotopically lighter than they are today. Shackleton and Kennett (1974) estimated the difference at 0.9 per mil, and argued that the isotopic change occurred between the middle and late Miocene. We have two good analyses in Core 6, Section 2 and Core 6, Section 3 (Zone N10) which are about 1.0 per mil negative with respect to the value we estimate for Holocene Uvigerina. From that point in time back, we assume a world ocean 0.9 per mil lighter than today.

Today the sea floor at the site, at a depth of 2086 meters, lies below the Antarctic Intermediate Water in North Atlantic Deep Water, at a temperature of $2.8^{\circ} \mathrm{C}$ and a salinity of $34.85^{\circ} \%$ (estimated from Fuglister, 1960). From calibration of Uvigerina in Recent sediments (Shackleton, 1974; unpublished data) we estimate that Uvigerina living at this point would analyze at about +3.15 per mil. Living at the same temperature in Antarctic Intermediate Water, the value would be about +2.90 per mil. The difference is because NADW is isotopically heavier than the bulk of the world oceans. For convenience we have assumed in discussion that the effect of NADW and of Antarctic ice disappeared simultaneously so that the isotopic composition of the water actually changed by about 1.2 per mil.

So far as planktonic foraminifera are concerned, we have assumed that the same type of water mass covered the site throughout its history. At the surface, as today, there has probably always been a higher salinity, so that true temperatures would be higher by a very few degrees than those estimated isotopically. We have not made adjustment for this because we suspect that we have not in fact sampled truly surface-dwelling species in parts of the sequence.

\section{SITE 357-SITE DESCRIPTION}

Site 357 lies on the eastern flank of the Rio Grande Rise and was drilled at a depth of 2086 meters. At present the site lies in the course of the NADW which extends from a depth of approximately 1000 to 2500 meters. Through most of its history, the site probably stood in the path of an intermediate water mass, not always deriving, however, from the North Atlantic.

Site 357 presently is located at $30^{\circ} \mathrm{S}$, and $30^{\circ} \mathrm{W}$. Reconstructions of plate motions in the South Atlantic (Ladd, 1974) suggests that the site may have been changed in latitude from close to $40^{\circ} \mathrm{S}$ in the Cretaceous to closer to $30^{\circ} \mathrm{S}$ as the Tertiary progressed.

Thus, dynamically, we have a ridge segment, intersecting an intermediate water mass, while slowly proceeding to the north in the subtropical zone from close to $40^{\circ}$ to $30^{\circ} \mathrm{S}$ latitude.

\section{CHARACTER OF SEDIMENT AND FOSSILS}

Unfortunately, the Rio Grande Rise is and apparently was in the past a locus of active sediment 


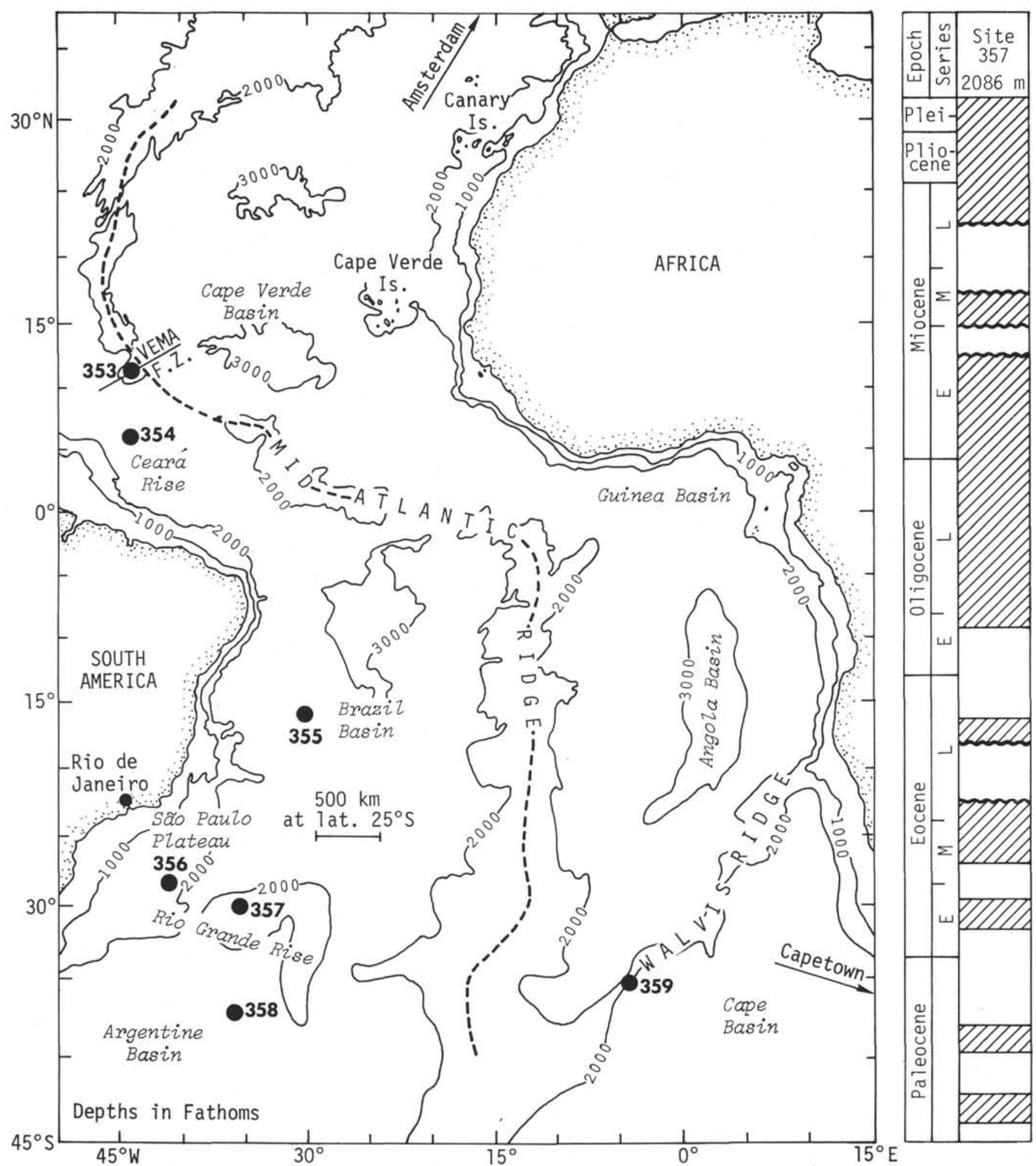

Figure 1. Location of Site 357 in the South Atlantic and the Tertiary stratigraphic column recovered at this site.

erosion, judging from the many hiatuses encountered in the sediment column at this site. In addition, redeposition of material and sediment mixing are commonly encountered in samples from Site 357. As can be seen in Figure 1, there are at least 9 hiatuses in the sedimentary column analyzed here. Most of these reflect sediment nondeposition or removal, although a couple are partially the result of a policy of discontinuous coring below the Miocene.

In addition, during a crucial part of the middle Eocene, a large volcanic sequence was deposited at our site along with some shallower foraminiferal debris and 
invertebrate fossils. As planktonic foraminifera are found mixed with shallow water benthic foraminifera (Boersma, this volume), there may have been enough downslope mixing in parts of the Eocene to slightly affect isotope temperature values. However, care was taken to avoid this; in many instances redeposited materials were of differing lithologies, colors, and states of preservation.

\section{FORAMINIFERAL MEASUREMENTS AND CALIBRATIONS}

In most samples at least one benthic and several planktonic foraminiferal species were analyzed.

Since the work of Duplessy et al. (1970), it has been known that different species may fractionate out of isotopic equilibrium. In addition, recent work by Grazzini (personal communication, 1975) has demonstrated a substantial isotopic difference between juveniles and adults of a planktonic species, as well as between winter and summer populations of a species. To obviate these problems we: (1) used calibrated benthic foraminifera where possible; (2) used adult planktonics of close to the same size in each analysis; (3) repeated analyses on multiple individuals of the same species; (4) used a number greater than nine individuals to average out the summer/winter differences in the planktonics; (5) attempted to calibrate additional benthic species for use in the Tertiary.

In several cases, where insufficient numbers of a benthic species were present, a sample of calibrated mixed species was used. In only a few cases in the early Eocene-Paleocene was a sample of random mixed benthics analyzed, and in those cases species known to present large deviations from equilibrium were avoided.

Reconstruction of a surface curve for the Paleogene requires the selection of an appropriate near-surface species. Globigerinoides, the "surface" planktonic of the Neogene did not exist prior to the late Oligocene. Analyses of multiple species of Paleogene planktonic foraminifera has demonstrated (Boersma and Shackleton, in press) that the keeled globorotalids (morozovellids) of the Paleogene consistently registered isotopically lower values (higher temperatures) than all other species analyzed except Chiloguembelina. Although there is evidence that the genus Chiloguembelina may have lived even shallower, the difference is at mid latitudes not sufficient to justify picking this group, and thus, the keeled globorotalids were used where possible as the surface zone planktonics in constructing large parts of the Paleogene surface curve.

As there are no keeled globorotalids in the Oligocene, the warmest species in each analysis was used to construct the points on the Oligocene and earliest Miocene segments of the curve. Globigerinoides did not become abundant at this site before planktonic Zone N.6 in the early Miocene. We believe that values plotted in Figure 2 for the Eocene are a good representation of surface temperature at the site, but that we have been less successful in deriving surface temperature for the Oligocene.

\section{UVIGERINA}

The calibration of Uvigerina was first suggested by Shackleton (1974) and is being presently demonstrated more extensively in recent samples. Shackleton found that Uvigerina precipitated its test very close to isotopic equilibrium with the surrounding water, and thus could be used as a reliable paleotemperature indicator. Uvigerina was abundant through much of the Tertiary at Site 357 and was used wherever possible to derive the values for the benthic curve. Shackleton (unpublished) in many Recent cores, has attempted to calibrate other benthic foraminiferal species to Uvigerina. As some of these are long ranging and can be found as far back as the early Tertiary, these species were used when Uvigerina was not present (For example, Pullenia bulloides, Globocassidulina subglobosa, and Oridorsalis umbonatus). In our Tertiary samples several Paleogene benthic species have been compared to Uvigerina and their calibration to Uvigerina is shown in Table 1. Thus, in some samples, these Paleogene species were analyzed (for example Nuttallides truempyi, Stilostomella abyssorum, and Osagularia mexicana). All species used in analyses are shown in Tables 2 and 3.

\section{TEMPERATURE RECORD AT THE SEA FLOOR}

Making the assumptions regarding the isotopic composition of the water discussed above, and assuming that the Paleogene benthic foraminifera analyzed depart to the same very small extent from isotopic equilibrium as has been shown for their recent relatives (Shackleton and Boersma, in preparation), temperatures may be estimated for the sea floor at Site 357 (see Figure 2). Two samples in the Paleocene and two in the early Eocene give values of $11^{\circ}$ to $12^{\circ} \mathrm{C}$ for a time when the site lay at bathyal depths and the paleolatitude was closer to $40^{\circ} \mathrm{S}$ (Ladd, 1974). Today, water of this temperature reaches around 500 meters, so that the warm pool of Atlantic water must have been substantially greater in extent.

A drop in temperature occurred during Zone P.11, and by P. 13 it was near $9^{\circ} \mathrm{C}$. There is a hiatus in the section above this zone, and a substantial drop to about $6^{\circ} \mathrm{C}$ has occurred by Zone P. 16 .

It appears that the sedimentary hiatus may be correlated with the temperature drop which would change the nature and velocity of bottom waters. Hiatuses across this time interval occur in other South Atlantic sites, including Leg 39, Site 356 and Leg 3, Sites 19 and 20C, which is a significantly deeper site. In these localities the only section of the upper Eocene present is a short interval of the nannofossil Isthmolithus recurvus Zone. Otherwise, parts of the upper middle and upper Eocene, and the lowermost Oligocene are all missing in the western South Atlantic.

Shackleton and Kennett (1974) reported a very sudden drop in bottom temperature in DSDP Site 277 in sediments believed to be of earliest Oligocene age; they interpreted this as the beginning of the formation 


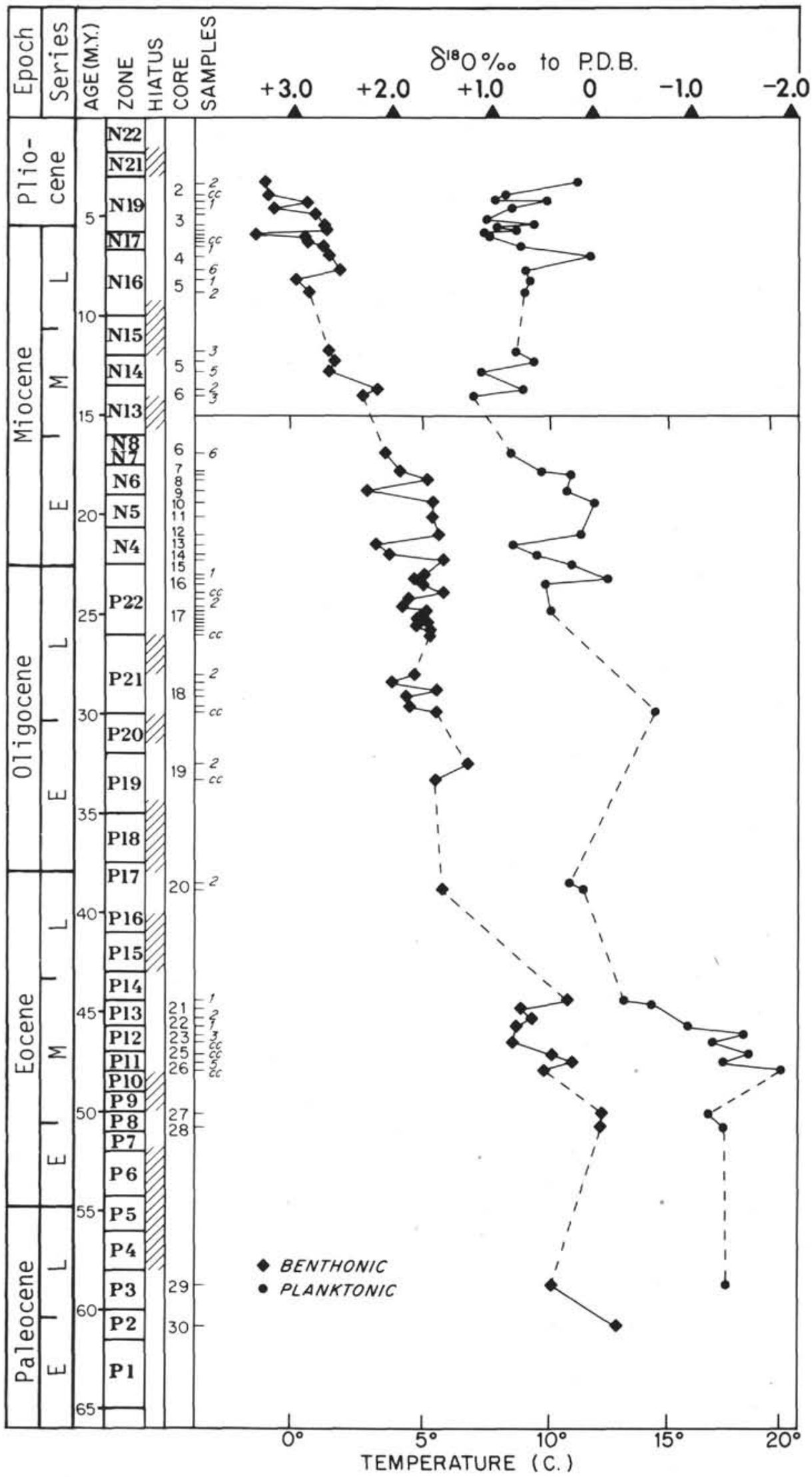

Figure 2. Temperature curve for benthic foraminifera (squares) and planktonic foraminifera (circles) during the Tertiary at Site 357. 
TABLE 1

Correction Factors Applied to Isotopic Measurements for the Construction of Figure 2

\begin{tabular}{lccc}
\hline \multicolumn{1}{c}{ Species } & 18 Adjustment & & ${ }^{13^{C} \text { Adjustment }}$ \\
\hline Uvigerina spinulosa & 0.00 & & 0.00 \\
Pullenia bulloides & 0.00 & $18_{0}$ & +0.40 \\
Stilostomella abyssorum & 0.00 & & +0.30 \\
Oridorsalis umbonatus & 0.00 & Raw measurements are & $?$ \\
Osangularia mexicana & -0.30 & isotopically heavier & -0.20 \\
Globocassidulina subglobosa & -0.10 & than Uvigerina & -0.30 \\
& & 180 & $?$ \\
Robulus occidental group & +0.10 & Raw measurements are & $?$ \\
Nodosarid & +0.10 & isotopically lighter & $?$ \\
Marginulina sp. & +0.20 & than Uvigerina & -0.60 \\
Nuttalides truempyi & +0.35 & & -0.80 \\
Anomalina illingi & +0.30 & & \\
Cibicides perlucidus & +0.40 & &
\end{tabular}

of very cold water at near-freezing temperatures around Antarctica, and, hence, the inception of an ocean structure similar to that prevailing today. Savin et al. (1975) also show a marked temperature drop, which occurred at least as early as Zone P.17 (DSDP 167, Sample 27, CC; Douglas and Savin, 1973). It seems certain that all these are the same event as that observed by us, and that the dramatic temperature drop did occur during the late Eocene rather than the earliest Oligocene.

Later in the Oligocene the sea-floor temperature at Site 357 dropped to about $4^{\circ}$ (in Zone P.21), returned to nearly $6^{\circ}$ early in Zone P.22, and fell to almost $3^{\circ}$ in Zone N.4 of the early Miocene. Douglas and Savin (1973) also show a temperature minimum in Zone P.21 (DSDP Site 167, Sample 13, CC). Such a drop in temperature may be evidence for an intensification in the rate of production of Antarctic bottom water.

In the early Miocene slightly higher temperatures are recorded in Zone N.5 (up to $5^{\circ} \mathrm{C}$ followed by a lower value in Zone N.6; samples in Zones N.7 and N.10 [ $3^{\circ}$ to $\left.4^{\circ} \mathrm{C}\right]$ ), are similarly cool for the mid Miocene.

In the late Miocene we see the effect of the build-up of the Antarctic ice sheet. It is not possible to determine whether the variation seen in Cores 3 and 4 are partly the result of inception of NADW production, or whether they represent the fluctuations in a growing ice sheet, or fluctuation in water temperature.

\section{TEMPERATURE HISTORY: PLANKTONIC FORAMINIFERA}

As has been clearly explained by Savin et al. (1975), it is difficult to estimate sea surface temperature from the oxygen isotopic composition of planktonic foraminifera, primarily due to the fact that most species do not actually deposit the bulk of their calcium carbonate at the ocean surface, and there is no known way of determining at what depth a now-extinct species lived. It is clear from Figure 2 that the average temperature at which planktonic species calcified has dropped during the Paleogene; almost certainly this is a reflection of a drop in temperature reflected through the water column. However, the actual temperature values are hard to interpret.
The highest temperature recorded is for a keeled globorotalid in Sample 26, CC and an acarininid in the same sample; these yield values of $19^{\circ}$ to $20^{\circ}$ using the assumptions discussed above. If they were living in surface water, this implies a temperature no higher than is experienced in similar latitudes today. Through the Oligocene we are measuring values in the range of $6^{\circ}$ to $12^{\circ}$, with nothing higher in the Miocene. As mentioned above, the Oligocene values may not be true surface values. However, both the Eocene section and the Miocene are probably valid surface temperature records.

\section{FAUNAL CHANGES CORRELATED WITH TEMPERATURE CHANGE}

Changes are recorded in the foraminiferal faunas during the intervals of significant change in temperature. A preliminary analysis was made on:

1) planktonic and benthic faunas during the temperature decline in the middle to late Eocene (Cores 20-22);

2) planktonic and benthic faunas at the temperature minimum in the late Oligocene (Cores 17-19);

3 ) benthic faunas at the early Miocene temperature decline in Core 9;

4) planktonic faunas during the temperature increase in Core 10 (early Miocene).

Several indices were used to characterize benthic faunas during times of temperature change:

Benthic Number (BN): As a simple measure of the abundance of benthic foraminifera, and hence the planktonic: benthic ratio, the benthic number was estimated from a sample of standard weight. In a preliminary analysis such as this, this simple index gives a first approximation of the abundance of the benthics, although a total picking of the sample would be more reliable in any detailed analysis of the faunas.

Ratio of rectilinear forms to rotaloid forms was used by Douglas (1973) and has been repeated here, as changes in this index appear to coincide with changes in the oxygen isotope record and thus with paleotemperature changes at the site.

Spinosity is a marker of differing environments; it has been found that some genera respond to changing 
TABLE 2

Benthic Foraminifera Used in Oxygen Isotope Analyses and Their

Delta ${ }^{18} 0$ Values - Site 357 - Delta ${ }^{18} \mathrm{O}$ to PDB Standard

\begin{tabular}{|c|c|c|c|c|c|c|}
\hline \multirow{3}{*}{$\begin{array}{c}\begin{array}{c}\text { Sample } \\
\text { (Interval in cm) }\end{array} \\
2-2,120 \\
2, \text { CC }\end{array}$} & \multirow{4}{*}{\begin{tabular}{l}
\multicolumn{1}{c}{ Species } \\
Uvigerina \\
Globocassidulina \\
+Pullenia \\
Uvigerina
\end{tabular}} & \multirow{2}{*}{$\begin{array}{c}\begin{array}{c}\text { Planktonic } \\
\text { Zone }\end{array} \\
\text { N19 }\end{array}$} & \multicolumn{2}{|c|}{$\begin{array}{c}\delta{ }^{13} \mathrm{C} \delta{ }^{18} \mathrm{O} \\
\text { (measured) }\end{array}$} & \multicolumn{2}{|c|}{$\begin{array}{c}{ }^{\delta}{ }^{13} \mathrm{C} \delta{ }^{18} \mathrm{O} \\
\text { (adjusted to } \\
\text { Uvigerina) }\end{array}$} \\
\hline & & & +0.11 & +3.29 & +0.11 & +3.29 \\
\hline & & N19 & 0.00 & 3.27 & & +3.22 \\
\hline $2, \mathrm{CC}$ & & · & +0.14 & +3.28 & +0.14 & $\begin{array}{l}+3.28 \\
+3.25^{b}\end{array}$ \\
\hline $3-1,120$ & $\begin{array}{l}\text { Globocassidulina } \\
\text { Uvigerina }\end{array}$ & N19 & $\begin{array}{l}-0.26 \\
+0.01\end{array}$ & $\begin{array}{l}+2.97 \\
+2.85\end{array}$ & +0.10 & $\begin{array}{l}+2.87 \\
+2.85 \\
+2.86 \mathrm{~b}\end{array}$ \\
\hline $3-2,120$ & $\begin{array}{l}\text { Globocassidulina } \\
\text { +Uvigerina } \\
\text { +Pullenia }\end{array}$ & N19 & -0.08 & +3.20 & -0.08 & +3.20 \\
\hline $3-3,40$ & Globocassidulina & N19 & -0.11 & +2.88 & -0.41 & +2.78 \\
\hline $3-5,40$ & Globocassidulina & $\mathrm{N} 17-19$ & -0.15 & +2.80 & -0.45 & +2.70 \\
\hline $3-6,120$ & Mixed benthics & $\begin{array}{l}\text { Late } \\
\text { Miocene }\end{array}$ & +0.79 & +3.38 & & +3.38 \\
\hline $4-2,120$ & $\begin{array}{l}\text { Pullenia } \\
\text { +Globocassidulina }\end{array}$ & $\begin{array}{l}\text { Late } \\
\text { Miocene }\end{array}$ & +0.55 & +2.75 & & +2.70 \\
\hline $4-4,20$ & Mixed benthics & $\begin{array}{l}\text { Late } \\
\text { Miocene }\end{array}$ & +0.33 & +2.65 & & +2.65 \\
\hline $4-6,120$ & Globocassidulina & $\begin{array}{l}\text { Late } \\
\text { Miocene }\end{array}$ & +0.39 & +2.54 & +0.09 & +2.44 \\
\hline & Uvigerina & & -0.05 & $+1.62^{\mathrm{a}}$ & & \\
\hline & Pullenia & & +0.16 & +2.63 & & $\begin{array}{l}+2.63 \\
+2.54^{b}\end{array}$ \\
\hline $5-1,130$ & Mixed benthics & $\begin{array}{l}\text { Late } \\
\text { Miocene }\end{array}$ & +0.68 & +2.97 & & +2.97 \\
\hline $5-2,120$ & Mixed benthics & $\begin{array}{l}\text { Late } \\
\text { Miocene }\end{array}$ & +0.74 & +2.84 & & +2.84 \\
\hline $5-3,40$ & Mixed benthics & N13-N14 & +0.22 & +2.51 & & \\
\hline $5-3,40$ & Globocassidulina & N13-14 & +0.38 & +2.89 & +0.08 & $\begin{array}{l}+2.79 \\
+2.65^{b}\end{array}$ \\
\hline $5-4,120$ & Mixed benthics & N13-14 & +0.21 & +2.59 & & +2.59 \\
\hline $5-5,120$ & Uvigerina & N13-14 & +0.17 & +2.64 & +0.17 & +2.64 \\
\hline $6-2,120$ & $\begin{array}{l}\text { Uvigerina } \\
\text { Mixed benthics }\end{array}$ & $\mathrm{N} 11-\mathrm{N} 12$ & $\begin{array}{l}+0.83 \\
+0.43\end{array}$ & $\begin{array}{l}+2.16 \\
+2.13\end{array}$ & +0.83 & $\begin{array}{l}+2.16 \\
+2.13 \\
+2.15^{b}\end{array}$ \\
\hline $6-3,40$ & $\begin{array}{l}\text { Uvigerina } \\
\text { Mixed benthics }\end{array}$ & N11-N12 & $\begin{array}{l}+1.22 \\
+0.89\end{array}$ & $\begin{array}{l}+2.17 \\
+2.43\end{array}$ & +1.22 & $\begin{array}{l}+2.17 \\
+2.43 \\
+2.30^{\mathrm{b}}\end{array}$ \\
\hline $6-6,120$ & Mixed benthics & N7 & +0.39 & +2.08 & & +2.08 \\
\hline $7-1,120$ & Uvigerina & N6 & +0.63 & +1.93 & +0.63 & +1.93 \\
\hline $7-4,140$ & Mixed benthics & N6 & +0.40 & +2.02 & & +2.02 \\
\hline $8-1,120$ & Mixed benthics & N6 & -0.12 & +1.65 & & +1.65 \\
\hline $9-2,120$ & $\begin{array}{l}\text { Pullenia } \\
\text { Globocassidulina }\end{array}$ & N6 & +0.88 & +2.31 & & +2.26 \\
\hline $10-2,120$ & Mixed benthics & N5 & +0.19 & +1.60 & & +1.60 \\
\hline $11-2,120$ & $\begin{array}{l}\text { Uvigerina } \\
+ \text { Stilostomella }\end{array}$ & N5 & +0.31 & +1.60 & +0.46 & +1.60 \\
\hline $12-6,120$ & Mixed benthics & N4 & +0.53 & +1.54 & & +1.54 \\
\hline $13-6,120$ & Mixed benthics & $\mathrm{N} 4$ & +0.93 & +2.17 & & +2.17 \\
\hline $14-2,40$ & Mixed benthics & $\mathrm{N} 4$ & +0.61 & +2.04 & & +2.04 \\
\hline $16-1,40$ & Uvigerina spinulosa & P22 & +0.13 & +1.68 & +0.13 & +1.68 \\
\hline $16-1,120$ & $\begin{array}{l}\text { Globocassidulina } \\
+ \text { Pullenia }\end{array}$ & P22 & +0.08 & +1.83 & & +1.78 \\
\hline $16-2,120$ & $U$. spinulosa & P22 & +0.18 & +1.78 & +0.18 & +1.78 \\
\hline & Stilostomella & & -0.18 & +1.74 & & +1.74 \\
\hline & Globocassidulina & & +0.49 & +1.56 & & +1.46 \\
\hline & Gyroidina & & +0.53 & $+1.97^{\mathrm{a}}$ & & \\
\hline & Oridorsalis & & -0.13 & +1.79 & & $\begin{array}{l}+1.79 \\
+1.69 \mathrm{~b}\end{array}$ \\
\hline $\begin{array}{l}16, \mathrm{CC} \\
17-2,38\end{array}$ & U. spinulosa & $\mathrm{P} 22$ & -0.25 & +1.49 & -0.25 & +1.49 \\
\hline $17-2,38$ & U. spinulosa & & +0.19 & +1.91 & +0.19 & +1.91 \\
\hline $17-2,38$ & Globocassidulina & & +0.42 & +1.87 & & +1.77 \\
\hline $17-2,38$ & Gyroidina & & +0.64 & $+1.46^{\mathrm{a}}$ & & +1.84 \\
\hline
\end{tabular}


TABLE 2 - Continued

\begin{tabular}{|c|c|c|c|c|c|c|}
\hline \multirow{2}{*}{$\begin{array}{c}\begin{array}{c}\text { Sample } \\
\text { (Interval in } \mathrm{cm} \text { ) }\end{array} \\
17-2,120\end{array}$} & Species & $\begin{array}{c}\text { Planktonic } \\
\text { Zone }\end{array}$ & \multicolumn{2}{|c|}{$\begin{array}{c}{ }^{8}{ }^{13} \mathrm{C} \delta{ }^{18} \mathrm{O} \\
\text { (measured) }\end{array}$} & \multicolumn{2}{|c|}{$\begin{array}{c}{ }^{13} \mathrm{C} \delta{ }^{18} \mathrm{O} \\
\text { (adjusted to } \\
\text { Uvigerina) }\end{array}$} \\
\hline & Oridorsalis & & -0.26 & +2.01 & & +2.01 \\
\hline & Gyroidina & & +0.23 & $+1.41^{\mathrm{a}}$ & & +1.88 \\
\hline & U. spinulosa & & +0.10 & +1.88 & & +1.88 \\
\hline & Globocassidulina & & +0.22 & +1.99 & & $\begin{array}{l}+1.89 \\
+1.92^{b}\end{array}$ \\
\hline \multirow[t]{7}{*}{$17-3,120$} & U. spinulosa & & -0.03 & +1.69 & -0.03 & +1.69 \\
\hline & Globocassidulina & & +0.12 & +1.71 & & +1.61 \\
\hline & Stilostomella & & -0.37 & +1.66 & & +1.66 \\
\hline & Mixed benthics & & -0.17 & +1.54 & & +1.63 \\
\hline & Plectofrondicularia & & -0.12 & +1.67 & & \\
\hline & Cibicides & & +0.59 & +1.29 & & +1.69 \\
\hline & Cibicides & & +0.30 & +1.15 & & $\begin{array}{l}+1.55 \\
+1.65^{b}\end{array}$ \\
\hline $17-4,40$ & $U$. spinulosa & & -0.03 & +1.70 & -0.03 & +1.70 \\
\hline $17-4,113$ & $U$. spinulosa & & -0.09 & +1.75 & -0.09 & +1.75 \\
\hline \multirow[t]{5}{*}{$17-5,40$} & U. spinulosa & & -0.12 & +1.60 & -0.12 & +1.60 \\
\hline & Globocassidulina & & +0.45 & +1.82 & & +1.72 \\
\hline & Globocassidulina & & +0.63 & +1.67 & & +1.57 \\
\hline & Cibicides & & +0.70 & +1.23 & & +1.63 \\
\hline & Nodosaria (large) & & -0.27 & +1.54 & & $\begin{array}{l}+1.64 \\
+1.64^{b}\end{array}$ \\
\hline \multirow{3}{*}{$17-5,120$} & Cibicides & & +0.65 & +1.48 & & +1.88 \\
\hline & $U$. spinulosa & & +0.18 & +1.80 & & +1.80 \\
\hline & Gavelinella & & +0.49 & +1.31 & & +1.61 \\
\hline $17-6,40$ & Mixed benthics & & -0.03 & +1.81 & & +1.81 \\
\hline \multirow[t]{2}{*}{$17, \mathrm{CC}$} & Mixed benthics & & +0.15 & +1.72 & & +1.63 \\
\hline & Gavilinella & & +0.53 & +1.23 & & +1.53 \\
\hline \multirow[t]{3}{*}{$18-2,40$} & U. spinulosa & $\mathrm{P} 21$ & +0.30 & +1.69 & +0.30 & +1.69 \\
\hline & Stilostomella & & -0.24 & +1.86 & & +1.86 \\
\hline & Globocassidulina & & +0.43 & +1.89 & & $\begin{array}{l}+1.79 \\
+1.78^{b}\end{array}$ \\
\hline \multirow[t]{3}{*}{$18-2,106$} & U. spinulosa & P22 & +0.07 & +1.92 & +0.07 & +1.92 \\
\hline & Globocassidulina & & +0.31 & +2.11 & & +2.01 \\
\hline & Anomalina & & -0.61 & +1.77 & & +2.07 \\
\hline $18-3,40$ & U. spinulosa & P21 & +0.22 & +1.55 & +0.22 & +1.55 \\
\hline $18-3,120$ & $U$. spinulosa & $\mathrm{P} 21$ & -0.05 & +1.86 & -0.05 & +1.86 \\
\hline $18-3,140$ & U. spinulosa & P21 & +0.34 & +1.83 & +0.34 & +1.83 \\
\hline $18, \mathrm{CC}$ & U. spinulosa & P21 & -0.08 & +1.56 & -0.08 & +1.56 \\
\hline $19-2,40$ & Mixed benthics & P19 & -0.70 & +1.24 & & \\
\hline \multirow[t]{2}{*}{$19, \mathrm{CC}$} & $\begin{array}{l}\text { Uvigerina } \\
\text { spinicostata }\end{array}$ & P19 & -0.08 & +1.51 & -0.08 & +1.51 \\
\hline & $\begin{array}{l}\text { Uvigerina } \\
\text { rippensis }\end{array}$ & & +0.18 & +1.62 & +0.18 & +1.62 \\
\hline $20-2,120$ & Stilostomella & P16 & +0.22 & +1.40 & & +1.50 \\
\hline \multirow[t]{2}{*}{$21-1,70$} & Nodosaria & P13 & +0.09 & +0.19 & & +0.29 \\
\hline & Gavelinella & & +1.01 & -0.11 & $\begin{array}{l}+0.21 \\
+0.21\end{array}$ & $\begin{array}{l}+0.19 \\
+0.24^{\mathrm{b}}\end{array}$ \\
\hline $21-1,210$ & Cibicides & P13 & +0.87 & +0.32 & +0.07 & +0.72 \\
\hline \multirow[t]{3}{*}{$21-2,40$} & U. spinicostata & P13 & +0.45 & +0.67 & +0.46 & +0.67 \\
\hline & Osangularia & & +0.71 & $+1.02^{\mathrm{a}}$ & & \\
\hline & Robulus & & -0.29 & +0.42 & & $\begin{array}{l}+0.52 \\
+0.62 \mathrm{~b}\end{array}$ \\
\hline \multirow[t]{6}{*}{$22-1,185$} & Mixed benthics & P13 & +0.50 & +0.77 & & \\
\hline & Mixed benthics & & -0.69 & +0.65 & & \\
\hline & Nodosarids & & -0.78 & +0.55 & & +0.65 \\
\hline & Anomalina & & +0.44 & +0.56 & & +0.86 \\
\hline & Gavelinella & & +0.52 & +0.50 & & +0.80 \\
\hline & Osangularia & & +0.15 & +1.06 & & \\
\hline $23-3,40$ & U. lappa & P12 & -0.03 & $-0.06^{\mathrm{a}}$ & & $+0.75^{b}$ \\
\hline \multirow{4}{*}{$23, \mathrm{CC}$} & Uvigerina sp. & $\mathrm{P} 12$ & -0.23 & +0.59 & -0.23 & +0.59 \\
\hline & $U$. rustica & & +0.59 & $+0.09^{\mathrm{a}}$ & & +0.09 \\
\hline & Nuttalides & & +0.28 & +0.78 & & +1.03 \\
\hline & Anomalina & & +0.12 & +0.45 & & $\begin{array}{l}+0.75 \\
+0.79 \mathrm{~b}\end{array}$ \\
\hline
\end{tabular}


TABLE 2 - Continued

\begin{tabular}{|c|c|c|c|c|c|c|}
\hline \multirow{2}{*}{$\begin{array}{c}\begin{array}{c}\text { Sample } \\
\text { (Interval in } \mathrm{cm})\end{array} \\
25, \mathrm{CC}\end{array}$} & \multirow{5}{*}{\begin{tabular}{l}
$\quad$ Species \\
\multicolumn{1}{c}{ Gyroidina } \\
Gavelinella \\
Globocassidulina \\
Marginulina
\end{tabular}} & \multirow{2}{*}{$\begin{array}{c}\begin{array}{c}\text { Planktonic } \\
\text { Zone }\end{array} \\
\text { P11 }\end{array}$} & \multicolumn{2}{|c|}{$\begin{array}{c}{ }^{\delta}{ }^{13} \mathrm{C} \delta{ }^{18} \mathrm{O} \\
\text { (measured) }\end{array}$} & \multicolumn{2}{|c|}{$\begin{array}{c}\delta^{13} \mathrm{C} \delta{ }^{18} \mathrm{O} \\
\text { (adjusted to } \\
\text { Uvigerina) }\end{array}$} \\
\hline & & & -0.09 & $+0.69^{\mathrm{a}}$ & & \\
\hline & & & +0.16 & -0.01 & & +0.29 \\
\hline & & & -0.32 & +0.55 & & +0.45 \\
\hline · & & & -0.73 & +0.22 & -0.52 & $\begin{array}{l}+0.42 \\
+0.39^{b}\end{array}$ \\
\hline $26-5,27$ & Osangularia & P11 & -0.37 & +0.42 & -0.57 & +0.12 \\
\hline & Mixed benthics & & -0.25 & +0.25 & & $\begin{array}{l}+0.25 \\
+0.19^{b}\end{array}$ \\
\hline $26, \mathrm{CC}$ & Gavelinella & P11 & +0.28 & +0.23 & & +0.53 \\
\hline & Stilostomella & & -0.54 & +0.41 & & +0.51 \\
\hline & Robulus & & -0.49 & +0.29 & & +0.39 \\
\hline & Nuttalides & & -0.45 & +0.09 & & +0.44 \\
\hline & Osangularia & & -0.43 & $+0.39^{a}$ & & \\
\hline & Bulimina & & -0.18 & $+0.36^{\mathrm{a}}$ & & \\
\hline & & & & & $-0.28^{b}$ & $-0.47^{b}$ \\
\hline $27-6,40$ & Mixed benthics & P8 & -0.34 & -0.11 & & -0.11 \\
\hline $28, \mathrm{CC}$ & Mixed benthics & P8 & +0.28 & -0.10 & & -0.10 \\
\hline $29-2,39$ & Gavelinella & P3 & +1.03 & +0.12 & +0.23 & +0.42 \\
\hline & Nuttalides & & +0.60 & +0.01 & & +0.36 \\
\hline & Pullenia & & +0.81 & +0.39 & & +0.39 \\
\hline & Mixed benthics & & +0.76 & +0.28 & & \\
\hline & Mixed benthics & & +1.00 & +0.49 & & \\
\hline & & & & & $+0.62^{b}$ & $+0.39^{b}$ \\
\hline $30-2,31$ & Mixed benthics & $\mathrm{P} 2$ & +0.19 & -0.26 & & \\
\hline
\end{tabular}

conditions by producing more spiny morphotypes. The degree of spinosity within a species as well as the number of spinose does appear to change during times of temperature change. This is true of both the rectilinear hyaline and some agglutinated foraminifera.

Diversity of benthic faunas changes irregularly, generally consistently with times of temperature change, but diversity in a standard sized sample is largely a function of the amount of planktonics accumulating at a site, as the greater planktonic abundance will affect both the BN and the diversity. However, as these values are not always parallel, there must be other factors affecting diversity at the site, particularly in closely spaced samples.

Generalists versus specialists: There are several deep marine species which may be called generalists and/or cosmopolitan. These species have long stratigraphic ranges, as well as wide vertical and geographic ranges. The number of these forms in populations appears to change during times of temperature change; increase in opportunistic species is often typical during an environmental crisis.

\section{Eocene}

Results of these analyses are shown in Figure 3.

In the middle to late Eocene planktonic faunal diversity plummets from an average of 16 species to an average of 5 during the temperature decline, leaving a monotonous fauna strongly dominated by Globigerinatheka spp. Lost are all the keeled globorotalids, acarininids, truncorotalids, hantkeninids, several globigerinids and most forms of Catapsydrax. A similar diversity decrease characterizes the late Eocene faunas at Leg 3, Sites 20C and 19 (Blow, 1970) which contain only $G$. senni and Globigerinatheka.

Among the benthics there is an increase in the ratio of rectilinear to rotalid forms. As rectilinear forms are supposed to characterize deeper (or cooler) faunas (see Vincent et al., 1975), an increase in rectilinear forms is to be expected during a cooling. Other changes include a drop in diversity, an increase in the planktonic/benthic ratio (the inverse of the benthic number measured here), an increase in spiny morphotypes, and an increase in the average size of individuals in the faunas. (Such a size increase may represent migration of larger individuals into this area, or simply be a function of increased redeposition of shallower individuals because of increased current activity.) In several samples there seems to be a noticeable increase in cosmopolitan forms such as Globocassidulina subglobosa, Pullenia bulloides, and Pullenia quinqueloba. These forms are called cosmopolites and/or generalists as they range widely bathymetrically, geographically, and stratigraphically. The uvigerinid present, changes from a primarily low costate morphotype Uvigerina rippensis, to a strongly hispido-costate one, Uvigerina spinicostata. As depth is not thought to have changed significantly during this time, the faunal changes must reflect changes in their associated water masses.

\section{Oligocene}

By the time of the Oligocene temperature minimum, the benthic fauna in general aspect resembles that of the Eocene. At the temperature minimum there is again an 
TABLE 3

Planktonic Foraminifera

\begin{tabular}{|c|c|c|}
\hline $\begin{array}{c}\text { Sample } \\
\text { (Interval in } \mathrm{cm} \text { ) }\end{array}$ & Species & ${ }^{18} \mathrm{O}$ \\
\hline $2-2,120$ & Globigerinoides spp. & +0.14 \\
\hline $2, \mathrm{CC}$ & Globigerinoides sacculifer & +0.86 \\
\hline $3-1,220$ & Globigerinoides conglobatus & +0.97 \\
\hline $3-2,120$ & Globigerinoides sacculifer & +0.45 \\
\hline $3-3,20$ & Globigerinoides spp. & +0.79 \\
\hline $3-3,120$ & Globigerinoides spp. & +0.80 \\
\hline $3-4,120$ & Globigerinoides spp. & +1.05 \\
\hline $3-5,120$ & Globigerinoides spp. & +0.95 \\
\hline $3-5,40$ & Globigerinoides spp. & +0.58 \\
\hline $3-6,40$ & Globigerinoides sacculifer & +0.65 \\
\hline $3-6,120$ & Globigerinoides sacculifer & +1.07 \\
\hline $3, \mathrm{CC}$ & Globigerinoides sacculifer & +1.02 \\
\hline $4-2,120$ & Globigerinoides spp. & +0.71 \\
\hline $4-4,20$ & Globigerinoides sacculifer & +0.01 \\
\hline $4-6,120$ & Globigerinoides sacculifer & +0.67 \\
\hline $5-1,130$ & Globigerinoides sacculifer & +0.62 \\
\hline $5-2,120$ & Globigerinoides sacculifer & +0.69 \\
\hline $5-3,40$ & Globigerinoides sacculifer & +0.76 \\
\hline $5-4,120$ & Globigerina spp. & +0.58 \\
\hline $5-5,120$ & Globigerina spp. & +1.11 \\
\hline $6-2,120$ & Globigerinoides sacculifer & +0.69 \\
\hline $6-3,40$ & Globigerinoides sacculifer & +1.19 \\
\hline $6-6,120$ & Globigerinoides sacculifer & +0.81 \\
\hline $7-1,120$ & Globigerina woodi & +0.50 \\
\hline \multirow[t]{2}{*}{$7-4,140$} & Globigerina woodi & +0.52 \\
\hline & Globigerinoides spp. & +0.21 \\
\hline \multirow[t]{2}{*}{$9-2,120$} & Globigerina woodi & +0.65 \\
\hline & Globigerinoides spp. & +0.25 \\
\hline $10-2,120$ & Globigerina spp. & -0.03 \\
\hline $12-6,120$ & Globigerina spp. & +0.11 \\
\hline $13-6,120$ & Globigerina spp. & +0.79 \\
\hline $14-2,40$ & Globigerina spp. & +0.55 \\
\hline $16-1,120$ & Globigerina praebulloides & -0.16 \\
\hline $16-2,120$ & Globorotalia opima & +0.46 \\
\hline $17-3,120$ & Globorotalia opima & +0.42 \\
\hline $18, \mathrm{CC}$ & Globigerina angulisuturalis & -0.64 \\
\hline $19, \mathrm{CC}$ & Globigerina spp. & +0.48 \\
\hline $20-2,40$ & Globigerapsis index & +0.22 \\
\hline $20-2,120$ & Globigerapsis index & +0.08 \\
\hline $21-1,70$ & Globigerapsis index & -0.33 \\
\hline $22-1,185$ & Acarinina densa & -0.97 \\
\hline $23-3,40$ & Keeled globorotalid & -1.53 \\
\hline $23, \mathrm{CC}$ & Keeled globorotalid & -1.22 \\
\hline $25, \mathrm{CC}$ & Keeled globorotalid & -1.59 \\
\hline $26-5,27$ & Acarinina densa & -1.33 \\
\hline $26, \mathrm{CC}$ & acarininid & -1.92 \\
\hline $27-6,40$ & Globigerina (S.) linaperta & -1.19 \\
\hline $28, \mathrm{CC}$ & Globorotalia (M.) aragonensis & -1.34 \\
\hline $29-2,40$ & Globorotalia (M.) velascoensis & -1.36 \\
\hline $30-2,31$ & Globorotalia (M.) pseudobulloides & $s-1.19$ \\
\hline
\end{tabular}

increase in the rectilinear forms at the expense of the rotaloid ones. Spiny morphotypes occur in abundance. Uvigerina spinulosa changes from finely striate to almost shaggy in appearance. The same sort of change can be seen on individuals of Stilostomella abyssorum which alter to $S$. abyssorum aculeata. There is, however, a decrease in the planktonic/benthic ratio, unlike in the Eocene cooling, and benthic diversity increases (Figure 3).

Among the planktonic foraminifera just prior to the temperature minimum Globigerina angiporoides, Chiloguembelina cubensis, and Globorotalia (T.) opima opima disappear from the faunas. Globigerinoides primordius does not appear at this site until the early Miocene. Planktonic diversity at the temperature minimum drops by about $25 \%$, but preservation of the faunas at the temperature minimum is markedly improved (Figure $3)$.

\section{Miocene}

The early Miocene changes in the benthic and planktonic faunas in Cores 9 and 10 are shown in Figures 4 and 5. An increase in surface temperature peaks in Section 10-1. Two important forms appear: abundant Globigerinoides altiaperturus, a form with a wide, gaping primary aperture; and a unique spiny morphotype (Plate 2, Boersma: Cenozoic planktonic foraminifera, this volume) remains in the fauna for a short time thereafter. The number of forms with bullae covering their apertures decreases and Globigerina woodi, also with a large primary aperture, increases markedly in abundance. The globoquadrinids and Globigerinoides spp. are more abundant during this temperature maximum.

From the plot of planktonic oxygen isotopic values, a change in the stratification of the planktonics can be seen to occur in the early Miocene (Section 10-1). The broader spread of planktonic values suggests wider and/or more complex stratification of isotherms. This sort of trend was reported for Recent planktonics from South to North in the Mozambique Channel by Vincent and Shackleton (1975).

Detailed measurement of the calcium carbonate values revealed no significant changes in the carbonate content during this time interval.

In the sequence of samples in Core 9 there are two major events in the benthic fauna. There is a major decrease in the planktonic/benthic ratio just prior to the temperature decrease and an increase in the planktonic/benthic ratio during the temperature low. Changes in the benthic fauna are more difficult to detect because of the low number of species and apparently intensified solution during this interval. Both the number of benthics and their diversity decrease. There is also an increase in the size of individuals, but no detectable change in the rectilinear: rotalid ratio.

We conclude that at times of significant change in ocean temperature, there is a concomitant response in the planktonic and/or the benthic foraminiferal faunas.

\section{CARBON ISOTOPES}

Co-existing species of benthonic foraminifera differ in carbon isotopic composition as well as oxygen isotopic composition; at present it is not known whether any are in carbon isotopic equilibrium with dissolved bicarbonate in the surrounding water or not. At the same time it is obviously necessary to eliminate variation which derives only from interspecific differences, if we are to obtain a record depicting changes in ocean dissolved bicarbonate carbon isotopic composition. In Figure 6 we show the deep-water carbon isotope record at Site 357 calibrated in terms of Uvigerina. Since our estimates of interspecific carbon 


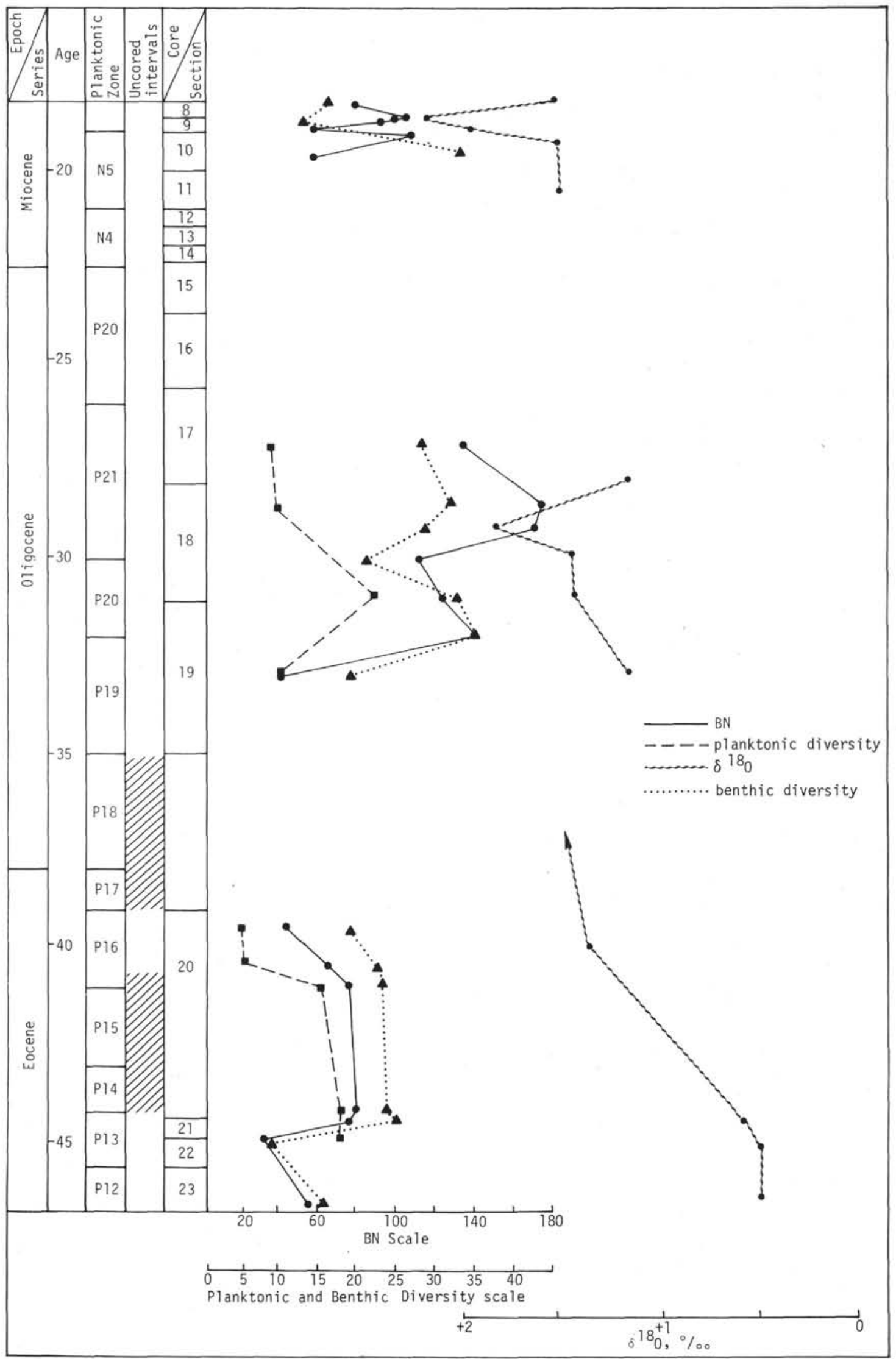

Figure 3. Benthic number, benthic diversity, and oxygen isotope record during selected intervals of the Tertiary at Site 357. 


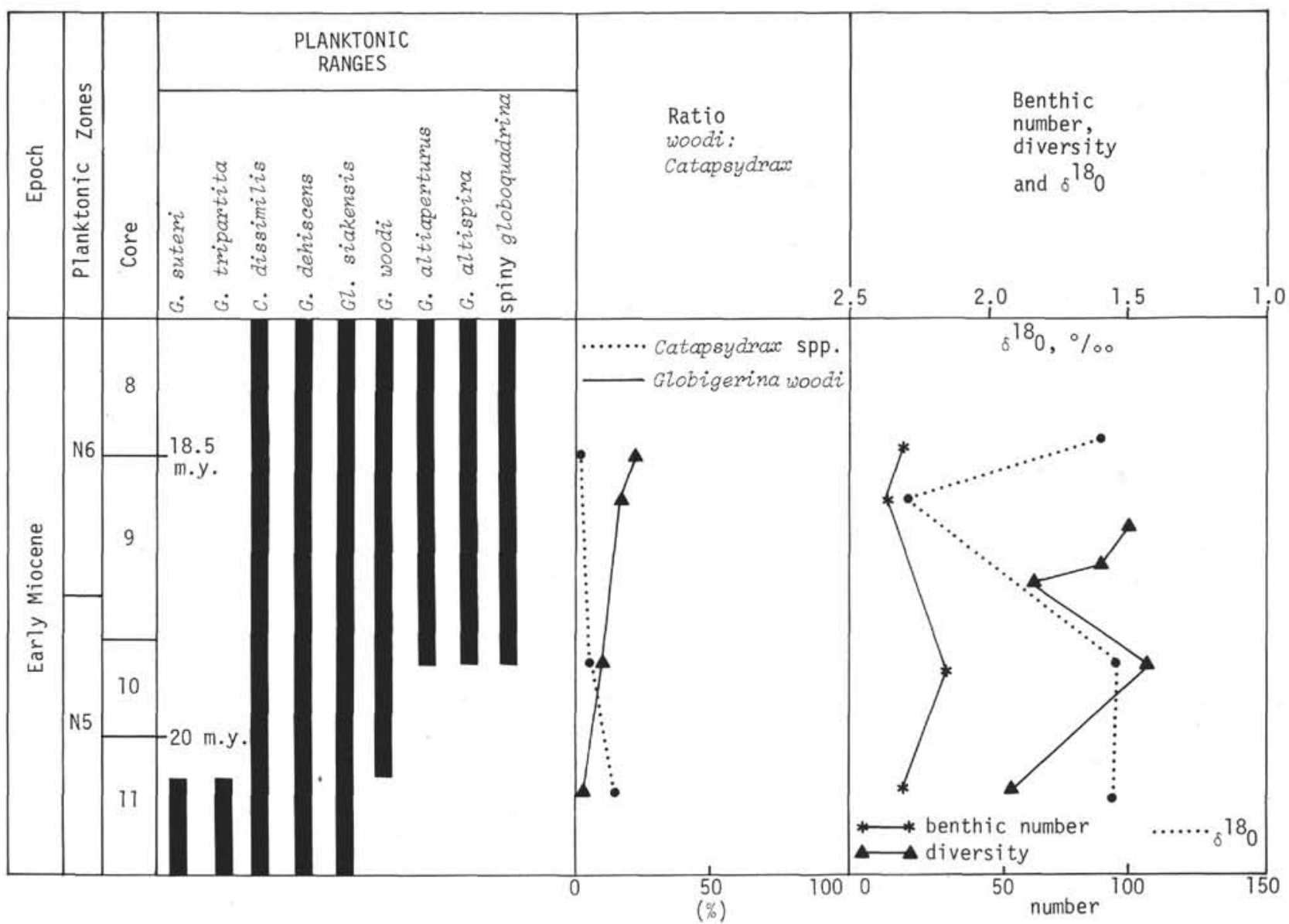

Figure 4. Stratigraphic ranges of selected Miocene planktonic foraminifera plotted against the changing ratio of Catapsydrax spp. to Globigerina woodi; the $\% \mathrm{CaCO}_{3}$ in this sequence; and the number and diversity of benthic foraminifera versus the paleotemperature curve for this segment of the Miocene.

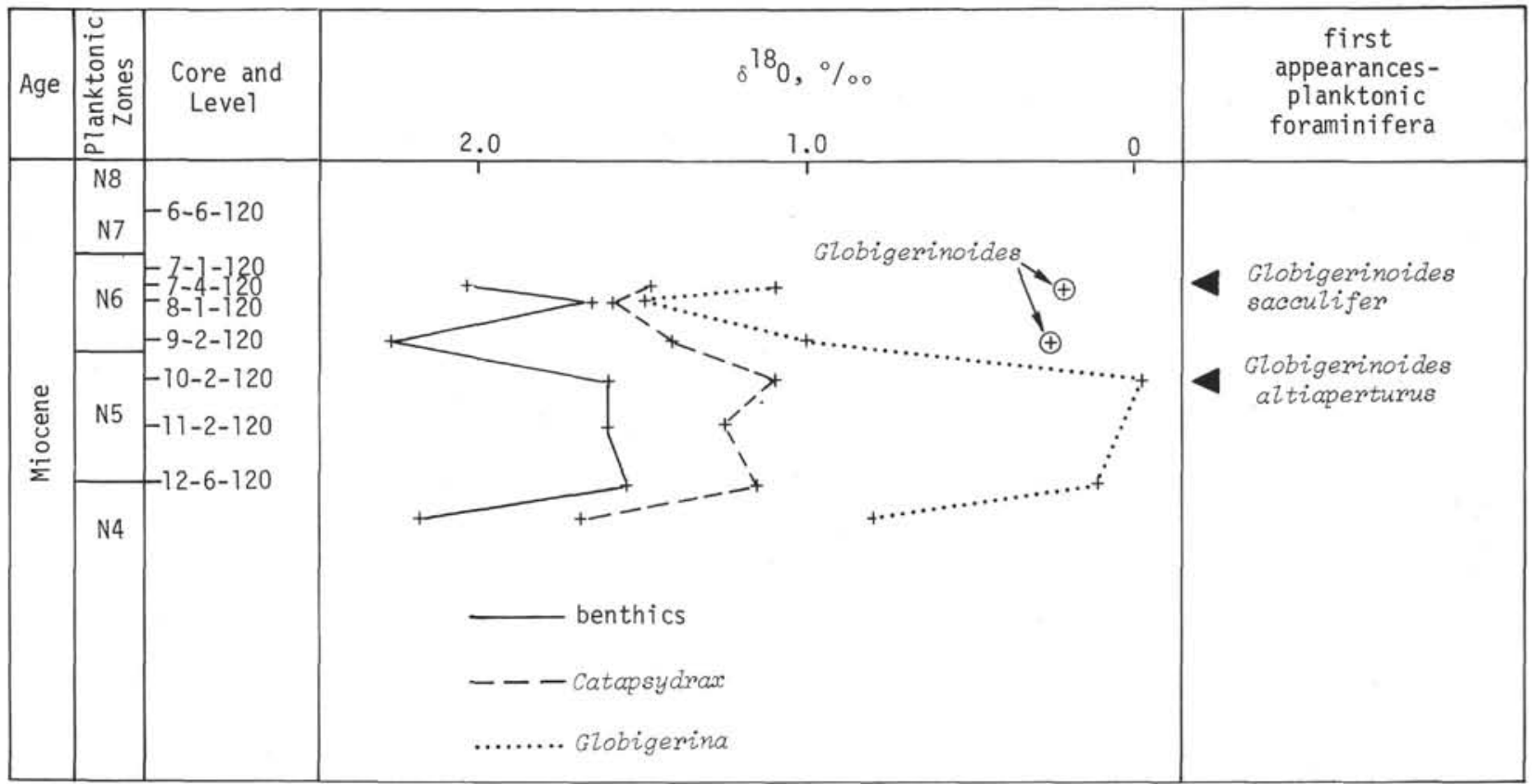

Figure 5. Changing relative stratification in the water column of the middle and deeper dwelling planktonic foraminifera Catapsydrax and the deeper globigerinids to the benthic foraminifera during the early Miocene. The surface-dwelling Globigerinoides was only found and plotted from two samples in this sequence. Note the squeezing together of the planktonics and the bottom forms during Zone N6 reflecting a steepening of the surface to bottom temperature gradients during this time. 


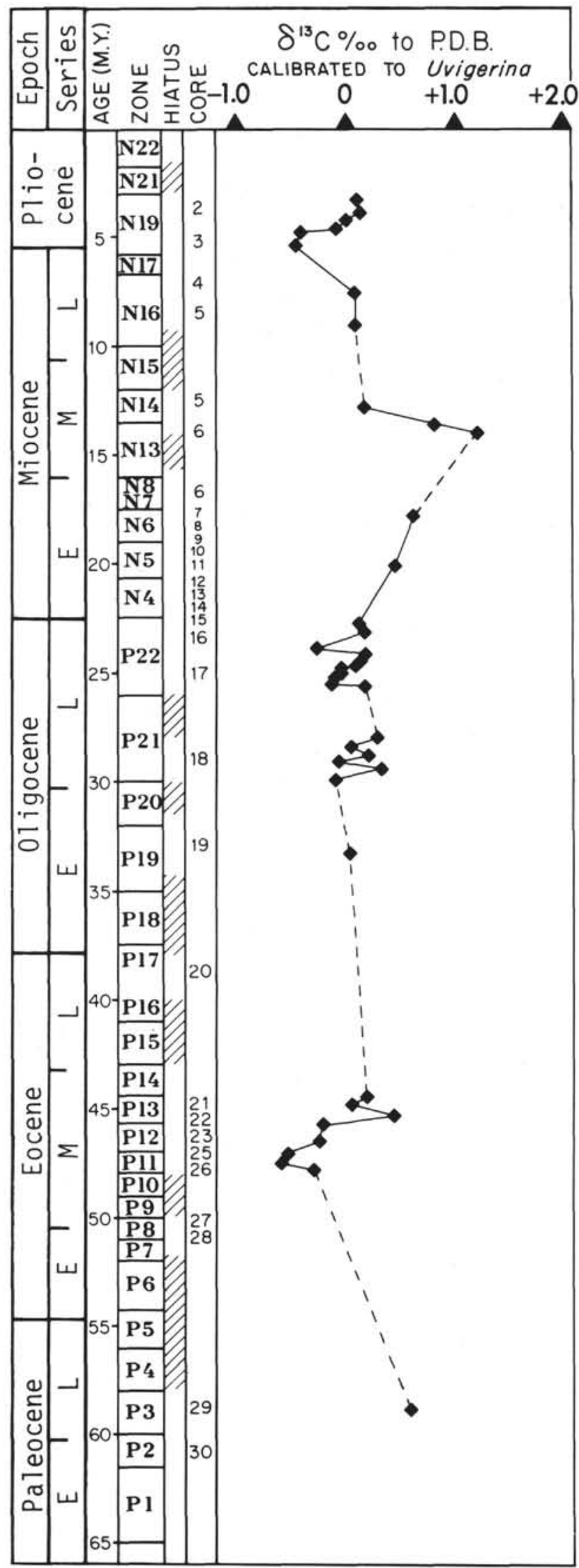

Figure 6. Carbon isotopic curve of benthic foraminifers at Site 357 through the Tertiary. isotopic differences are preliminary and incomplete, this record may be subject to modification. However, we have not plotted values from samples in which we analyzed mixed species or single species for which we have inadequate calibrations.

The deep-water carbon isotope record may reflect both changes in the carbon isotopic composition of the ocean dissolved carbon reservoir, and changes in the pattern of spatial carbon isotopic variation reflecting water mass movement. At this stage we would only point out that at least some of the events depicted in Figure 3 do probably reflect worldwide events. Both the unusually light carbon isotope values in the late Miocene, and the unusually heavy values in the middle Miocene, may be noticed in the records shown by Shackleton and Kennett (1974).

TABLE 4

Oxygen Isotopic Composition of Catapsydrax, Site $357 \%$ to PDB

\begin{tabular}{cc}
\hline $\begin{array}{c}\text { Sample } \\
\text { (Interval in cm) }\end{array}$ & $18_{0}$ \\
\hline $7-4,140$ & +1.47 \\
$8-1,120$ & +1.59 \\
$9-2,120$ & +1.41 \\
$10-2,120$ & +1.09 \\
$11-2,120$ & +1.24 \\
$12-6,120$ & +1.14 \\
$13-6,120$ & +1.69 \\
\hline
\end{tabular}

TABLE 5

Oxygen Isotopic Composition of Globigerina, Site 357 "Deep Forms" $\%$ to PDB

\begin{tabular}{ll}
\hline $\begin{array}{c}\text { Sample } \\
\text { (Interval in cm) }\end{array}$ & $18_{0}$ \\
\hline $7-4,140$ & +1.10 \\
$8-1,120$ & +1.49 \\
$9-2,120$ & +1.00 \\
$10-2,120$ & -0.03 \\
$11-2,120$ & \\
$12-6,120$ & +0.11 \\
$13-6,120$ & +0.79 \\
\hline
\end{tabular}

\section{ACKNOWLEDGMENTS}

We thank M.A. Hall for his careful operation of the V.G. Micromass mass spectrometer on which the analyses were made.

The authors would like to thank the DSDP for inviting one of us (A.B.) to participate in Leg 39. We would also like to thank the DSDP Staff at Lamont-Doherty for providing additional samples. This research has been partially funded by NSF Grant Oce-74-24110 and by NERC Grant GR3-1762.

\section{REFERENCES}

Blow, W.H., 1970. Deep Sea Drilling Project-Leg 3, foraminifera from selected samples. In Maxwell, A.E., von Herzen, R., et al., Initial Reports of the Deep Sea Drilling Project, Volume 3: Washington (U.S. Government Printing Office), p. 629-663. 
Douglas, R.G., 1973. Benthonic foraminiferal biostratigraphy in the Central North Pacific, Leg 17, Deep Sea Drilling Project. In Winterer, E., Riedel, W.R., et al., Initial Reports of the Deep Sea Drilling Project, Volume 17: Washington (U.S. Government Printing Office), p. 607-672.

Douglas, R.G., and Savin, S.M., 1973. Oxygen and carbon isotope analyses of Cretaceous and Tertiary foraminifera from the Central North Pacific. In Winterer, E.L., Riedel, W.R., et al., Initial Reports of the Deep Sea Drilling Project, Volume 17: Washington (U.S. Government Printing Office), p. 591-605.

Duplessy, J.C., Lalou, C., and Vinot, A.C., 1970. Differential isotopic fractionation in benthic foraminifera and paleotemperatures reassessed: Science, v. 168, p. 250-251.

Epstein, S., Buchsbaum, R., Lowenstam, H.A., and Urey, H.C., 1953. Revised carbonate-water isotopic temperature scale: Geol. Soc. Am. Bull., v. 64, p. 1315-1326.

Fuglister, F.C., 1960. Atlantic Ocean Atlas: Woods Hole Oceanographic Institute, Woods Hole, Mass.

Ladd, J.W., 1974. South Atlantic sea floor spreading and Caribbean tectonics: Ph.D. Thesis, Columbia University, New York.

Savin, S.M., Douglas, R.G., and Stehli, F.G., 1975. Tertiary marine paleotemperatures: Geol. Soc. Am. Bull., v. 86, p. $1499-1510$.
Shackleton, N.J., 1974. Attainment of isotopic equilibrium between ocean water and the benthonic foraminiferal genus Uvigerina: isotopic changes in the ocean during the last glacial: C.N.R.S. Colloq. 219, p. 203-209.

Shackleton, N.J. and Kennett, J.P., 1974. Paleotemperature history of the Cenozoic and the initiation of Antarctic glaciation: oxygen and carbon isotope analysis in DSDP Sites 277, 279, 281. In Kennett, J.P., Houtz, R.E., et al., Initial Reports of the Deep Sea Drilling Project, Volume 29: Washington (U.S. Government Printing Office), p. $743-755$.

Shackleton, N.J. and Opdyke, N.D., 1973. Oxygen isotope and palaeomagnetic stratigraphy of equatorial Pacific Core V28-238: Oxygen isotope temperatures and ice volumes on a $10^{5}$ year and $10^{6}$ year scale: Quat. Res., v. 3, p. 39-55.

Shackleton, N. and Vincent, E., in preparation. Oxygen and carbon isotope studies in Recent foraminifera from the Mozambique Channel Region: in preparation.

Vincent, E., Gibson, J.M., and Brun, L., 1974. Paleocene and early Eocene microfacies, benthonic foraminifera, and paleobathymetry of Deep Sea Drilling Project Sites 236 and 237, western Indian Ocean. In Fisher, R.L., Bunce, E.T., et al., Initial Reports of the Deep Sea Drilling Project, Volume 24: Washington (U.S. Government Printing Office), p. 859-885. 